\title{
Unified Evaluation of Consolidation Parameters for Low to High Plastic Range of Cohesive Soils
}

\author{
Zia ur Rehman ${ }^{1,2}$, Khalid Farooq ${ }^{2 a}$, Hassan Mujtaba ${ }^{2 b}$, Usama Khalid ${ }^{3}$ \\ RECEIVED ON 13.11.2019, ACCEPTED ON 19.05.2020
}

\begin{abstract}
Knowing the engineering properties of geomaterials is imperative to make the right decision while designing and executing any geotechnical project. For the economical and safe geotechnical design, quick characterization of the compressibility properties of the cohesive soil is often desirable; these properties are indeed tedious to determine through actual tests. Therefore, correlating the consolidation parameters of the soils with its index properties has a great significance in the geotechnical engineering field. Several attempts have been made in the past to develop correlations between the consolidation parameters and index properties of the cohesive soils, within certain limitations. However, there is still a need to develop such correlations based on the extensive database, composing of unified plasticity range of soils, i.e., low to high plasticity. In the current study, 148 undisturbed soil specimens were obtained from different areas of Pakistan. Out of which 120 samples were utilized to develop correlations, and 28 samples were used to check the validity of the developed correlations. In order to enhance the index properties database, 30 more bentonite mixed soil samples were prepared and tested accordingly. Correlations to envisage different consolidation parameters such as compression index, compression ratio and coefficient of volume compressibility were developed using 150 cohesive soil samples of low to high plasticity. In addition, the performance of these developed correlations was verified on a set of $\mathbf{4 0}$ soil samples and compared with the performance of different correlations available in the literature. The percentage deviation in the prediction of compressibility characteristics through developed correlations in the present study was found to be very less, which endorsed the excellent reliability of the developed correlations.
\end{abstract}

Keywords: Correlation, Index Properties, Consolidation Parameters, Compression Index, Pakistani Soils

\section{INTRODUCTION}

$\mathrm{T}$ The compressibility of the soils is an important consideration for civil engineering projects. Constructing a civil structure on the compressible soil layer could lead to the consolidation settlement; the quantitative head of consolidation settlement is computed by using various compressibility indices also known as consolidation parameters of soils, such as "Compression index" $\left(\mathrm{C}_{\mathrm{c}}\right)$ and "Coefficient of volume compressibility" $\left(\mathrm{m}_{\mathrm{v}}\right)$. One-dimensional, 1D, Oedometer experiment is performed to characterize these consolidation parameters of the soil. However, the 1D Oedometer test is expensive and tedious to conduct, as it requires an undisturbed sample and a couple of weeks for the completion. For correlating the consolidation parameters with a simpler and quicker method, several

${ }^{1}$ State Key Laboratory of Hydroscience and Engineering, Tsinghua University, Beijing, China.

Email: engr.zrehman@ gmail.com (Corresponding Author)

${ }^{2}$ Department of Civil Engineering, University of Engineering and Technology, Lahore, Pakistan.

Email: ${ }^{a k f c h @ u e t . e d u . p k, ~ b h a s s a n m u j t a b a @ u e t . e d u . p k ~}$

${ }^{3}$ Department of Civil Engineering, COMSATS University, Sahiwal, Pakistan.

Email: usama.khalid@ ciitsahiwal.edu.pk

This is an open access article published by Mehran University of Engineering and Technology, Jamshoro under CC BY 4.0 International License. 
attempts have been carried out in the past. Numerous researchers have developed correlations between consolidation parameters and index properties of soils [1-35] because index properties of soil can be quickly determined through simpler tests and can give a brief idea about the soil characteristics. Skempton [1] was the first to develop such a correlation among compression index $\left(\mathrm{C}_{\mathrm{c}}\right)$ and liquid limit $(\mathrm{LL})$ as follows:

$\mathrm{C}_{\mathrm{c}}=0.007(\mathrm{LL}-10)$

Similarly, Terzaghi and Peck [2] developed such a correlation for normally consolidated soils as follow:

$\mathrm{C}_{\mathrm{c}}=0.009(\mathrm{LL}-12)$

These correlations are still widely utilized to predict $C c$ value. Various correlations developed by different researchers to predict consolidation parameters are presented in Table 1. A number of researchers have engaged different soil parameters for the correlation with compression index, $\mathrm{C}_{\mathrm{c}}$ such as "Liquid Limit" (LL), "Plastic Limit" (PL), "Plasticity Index," (PI), "Shrinkage Index" (SI), "in situ void ratio" $\left(e_{0}\right)$, and "void ratio at liquid limit" $\left(e_{\mathrm{L}}\right)[3-5,7-8,10,12,14$, 18, 20, 23, 30, 32-35]. Few researchers have also developed correlations for the "compression ratio" (i.e., $\left.\mathrm{C}_{\mathrm{c}}{ }^{\prime}=\mathrm{C}_{\mathrm{c}} /\left(1+\mathrm{e}_{0}\right)\right)$ using index properties of soils [4, 18]. However, correlations for the prediction of the $m_{v}$ have been ignored in past studies. In contrast, $\mathrm{mv}$ is also a critical parameter, often utilized to compute the consolidation settlement and permeability of soils.

The abundance of the correlations to envisage the compressibility indices of soil in the literature suggests that a single correlation cannot be well suited to be generalized for the prediction of consolidation parameters for all kinds of soils. This means that usefulness of the available correlations to envisage consolidation parameters is limited within certain bounds. Such bounds are often defined based on the soil plasticity, geological locations, and soil types. The selection of suitable correlations from the literature may require a detailed and cumbersome investigation [36-37]. Generally, a limited plasticity database has been used for the development of such correlations in the past, which restrains the applicability of these correlations within specific plasticity ranges of cohesive soils. Therefore, to create generality, it is needed to develop correlations based on an extensive plasticity database of cohesive soils (such as low to high plastic cohesive soils). Besides, there is a scarcity of literature on the development of such correlations using locally available soils in Pakistan, which contains a vast plasticity range. Thus, such correlations are indeed needed to be developed using locally available soil of Pakistan; these correlations could be of great importance for the concerned practitioners dealing with Pakistani soils and looking for generalized correlations for different plasticity range of soil.

Considering the aforementioned research opportunities, the present study aims to establish the generalized correlations for the prediction of consolidation indices/parameters such as $\mathrm{C}_{\mathrm{c}}, \mathrm{C}_{\mathrm{c}}{ }^{\prime}$, and $\mathrm{m}_{\mathrm{v}}$ for the low to high plasticity range of the cohesive soils, by testing soil samples of a broad plasticity range. The soil samples are collected from different parts of Pakistan. Thus, these correlations can be of local importance as well as of global importance because of the extensive plasticity database.

\section{METHODOLOGY}

The current study aims to develop the generalized correlations among consolidation parameters $\left(\mathrm{C}_{\mathrm{c}}, \mathrm{C}_{\mathrm{c}}\right.$, and $\mathrm{m}_{\mathrm{v}}$ values) and index properties of the cohesive soils, using locally available cohesive soils of broad plasticity range (low to high plastic) in Pakistan. For this purpose, soil specimens were collected from various parts of Pakistan. One hundred forty-eight undisturbed soil samples were collected as per ASTM D7015-13 from different areas of Pakistan. Out of these, 120 samples were used for the development of correlations, and 28 samples were used for checking the validity of developed correlations. The undisturbed soil sample collection map is presented in Fig. 1.

In order to enhance the database of soil samples, commercially available bentonite was mixed with soils taken from Harbanspura (Lahore), Nandipur (Gujranwala), and DG Khan in varying percentages. 10 Soil-Bentonite Mixture (SBM) samples were prepared by blending the bentonite at an incremental 
rate of 5\% in Harbanspura soil (Lahore); 6 SBM samples were prepared by blending the bentonite in Nandipur (Gujranwala) soil at an incremental rate of 5\%; 10 SBM samples were prepared by compositing the bentonite with DG Khan soil at an incremental rate of $2.5 \%$. Four samples were further obtained by integrating varying percentages of Harbnspura (Lahore) and Nandipur (Gujranwala) soils. Numerous laboratory tests were carried out on subjected soil samples such as sieve and hydrometer analysis, specific gravity tests, consistency limits tests, compaction tests (only for remolded soils), 1D Oedometer tests (consolidation tests) as per ASTM standards [38-43].

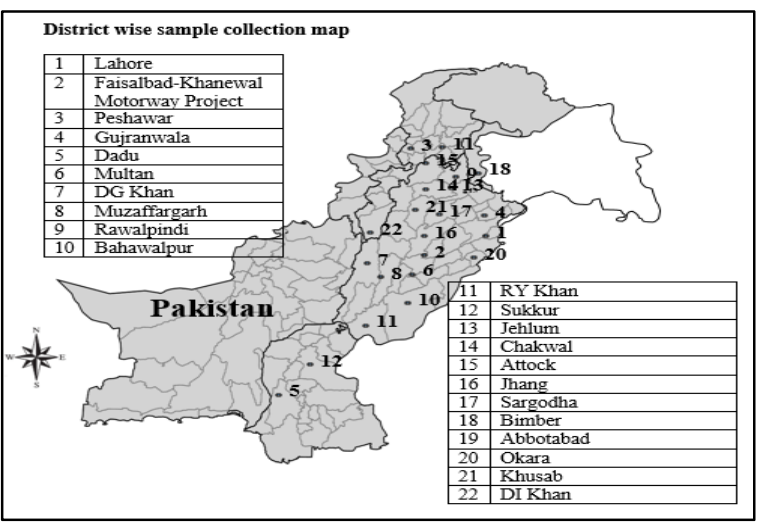

Fig. 1: Soil Sample Collection Map

A 1D Oedometer test was performed to apprehend the consolidation parameters of soils. In the 1D Oedometer test, the soil sample was restrained laterally and loaded axially under precise increments of the stress. The increment of stress was applied each time until pore water dissipation was ceased for the subjected increment of stress. For each successive increment of load, a double load was applied from the preceding load, so that Load Increment Ratio (LIR) can be maintained at unity. The minimum load increment duration was taken as 24 hours. Whereas, each successive load decrement was taken to be $1 / 4$ of the previous load, during the unloading phase [43]. During the 1D Oedometer test, the measurements were made of the height change of the soil sample. This test results data was then used to evaluate the values of consolidation parameters by drawing a relationship between void ratio or strain and effective stress.
1D Oedometer test was conducted mainly on undisturbed soil samples collected from various areas of Pakistan (Fig. 1), albeit some remolded soil samples were also tested. Undisturbed soil specimens were recovered from a varying depth below $1 \mathrm{~m}$ of natural surface level. Artificially mixed soil samples were remolded at the maximum dry density and Optimum Moisture Content (OMC) using standard effort (ASTM D698) to get the normally consolidated samples in line with the obtained undisturbed samples [42]. For that purpose, after determining the maximum dry density and optimum moisture content of artificially mixed samples using standard efforts, these samples were remolded at their standard maximum dry density and optimum moisture content in a compaction mold. After carefully extruding these samples from compaction mold, the samples were then carefully extracted in a consolidation ring. A total of 150 cohesive soil specimens were tested for the establishment of correlations, and 28 soil specimens were tested to check the validity of developed correlations.

\section{TEST RESULTS}

150 samples were selected to develop correlations for compressibility characteristics. All laboratory test results of these samples are briefly presented in Table 1 and concisely described.

The grain size distribution analysis of all of these selected samples showed that the percentage of gravel was ranging from $0 \%$ to $11 \%$, sand $1 \%$ to $32 \%$, and fines $68 \%$ to $99 \%$ (Fig. 2a). Hydrometer analysis results showed that the percentage of silts in the soil samples was ranging from $26 \%-94 \%$ and clay $4 \%$ $72 \%$ (Fig. 2(a)). The specific gravity values of the soil samples were observed to be in the range of 2.65 to 2.75 , with an average of 2.7 .

The fines percentage in the soil samples had the LL values in a range of $22 \%-129 \%$, and PI was in the range of 2\%-106\%. General range of $P I$ to distinguish plasticity is given in Table 2 . Based on plasticity and grain size distribution results, selected samples were classified under USCS, as described in [44]. Soil samples were classified as low plastic silt (ML), silty clay (CL-ML), low plastic clay (CL), and high plastic 
clay $(\mathrm{CH})$. Fig. 2(b) presents a plot of all the selected samples on the A-line Chart.

\begin{tabular}{|c|c|c|}
\hline \multicolumn{3}{|c|}{$\begin{array}{l}\text { Table 1: Predictive Correlations for Compressibility } \\
\text { Characteristics }\end{array}$} \\
\hline Correlation & Applicability & Reference \\
\hline$C_{c}=0.006($ LL-9) & $\begin{array}{l}\text { All natural } \\
\text { soils }\end{array}$ & Azzouz et al. [4] \\
\hline $\mathrm{C}_{\mathrm{c}}{ }^{\prime}=0.002(\mathrm{LL}+9)$ & $\begin{array}{c}\text { All natural } \\
\text { soils }\end{array}$ & Azzouz et al. [4] \\
\hline $\mathrm{C}_{\mathrm{c}}=0.0015 \mathrm{Wn}$ & $\begin{array}{l}\text { Organic Clays } \\
\quad \& \text { Silts }\end{array}$ & Bowles [5] \\
\hline $\mathrm{C}_{\mathrm{c}}=0.208 \mathrm{e}_{0}+0.0083$ & Chicago clays & Bowles [5] \\
\hline $\mathrm{C}_{\mathrm{c}}=0.156 \mathrm{e}_{0}+0.0107$ & All Clays & Bowles [5] \\
\hline $\mathrm{C}_{\mathrm{c}}=0.329[20]$ & $\begin{array}{l}\text { Remolded } \\
\text { Clays }\end{array}$ & Carrier [7] \\
\hline $\mathrm{C}_{\mathrm{c}}=0.29\left(\mathrm{e}_{0}-0.27\right)$ & Silty Clays & Hough [9] \\
\hline$C_{c}=0.0046($ LL-9) & Brazilian Clay & Hough [9] \\
\hline $\mathrm{C}_{\mathrm{c}}=0.01 \mathrm{w}_{\mathrm{n}}$ & Chicago clays & Osterberg [10] \\
\hline $\mathrm{C}_{\mathrm{c}}=1.325 \mathrm{PI}$ & All Clays & Koppula [11] \\
\hline $\mathrm{C}_{\mathrm{c}}=\mathrm{PI} / 74$ & $\begin{array}{l}\text { Remolded } \\
\text { Clays }\end{array}$ & $\begin{array}{l}\text { Kulhawy and } \\
\text { Mayne [12] }\end{array}$ \\
\hline $\mathrm{C}_{\mathrm{c}}=0.0096($ LL-9) & Brazilian Clay & Cozzolino [14] \\
\hline $\mathrm{C}_{\mathrm{c}}=0.2237 \mathrm{e}_{\mathrm{L}}$ & $\begin{array}{l}\text { Remolded } \\
\text { Clays }\end{array}$ & $\begin{array}{l}\text { Nagaraj and } \\
\text { Murthy [15] }\end{array}$ \\
\hline $\mathrm{C}_{\mathrm{c}}=0.2237 \mathrm{e}_{\mathrm{L}}$ & $\begin{array}{l}\text { Remolded } \\
\text { Clays }\end{array}$ & $\begin{array}{l}\text { Nagaraj and } \\
\text { Murthy [15] }\end{array}$ \\
\hline $\mathrm{C}_{\mathrm{c}}=0.0124 \mathrm{LL}-0.1761$ & All Clays & $\begin{array}{c}\text { Nath and } \\
\text { Dedalal, [16] }\end{array}$ \\
\hline $\mathrm{C}_{\mathrm{c}}=0.0150 \mathrm{PI}-0.0198$ & All Clays & $\begin{array}{c}\text { Nath and Dedalal } \\
{[16]}\end{array}$ \\
\hline $\begin{aligned} \mathrm{C}_{\mathrm{c}}{ }^{\prime}= & 0.0021 \mathrm{LL}+ \\
& 0.0587\end{aligned}$ & $\begin{array}{l}\text { Remolded } \\
\text { Clays }\end{array}$ & $\begin{array}{c}\text { Nath and Dedalal } \\
{[16]}\end{array}$ \\
\hline $\mathrm{C}_{\mathrm{c}}^{\prime}=0.0025 \mathrm{PI}+0.0866$ & $\begin{array}{l}\text { Remolded } \\
\text { Clays }\end{array}$ & $\begin{array}{c}\text { Nath and } \\
\text { Dedalal, [16] }\end{array}$ \\
\hline $\mathrm{C}_{\mathrm{c}}=1.15\left(\mathrm{e}_{0}-0.35\right)$ & All Clays & Nishida [17] \\
\hline $\begin{array}{c}\mathrm{C}_{\mathrm{c}}=0.002 \mathrm{PI}+0.0025 \mathrm{LL}- \\
0.005\end{array}$ & Indian soils & $\begin{array}{l}\text { Amardeep and } \\
\text { Shahid [21] }\end{array}$ \\
\hline $\mathrm{C}_{\mathrm{c}}=0.75\left(\mathrm{e}_{0}-0.50\right)$ & $\begin{array}{l}\text { Very Low } \\
\text { Plastic Clays }\end{array}$ & $\begin{array}{l}\text { Sowers and } \\
\text { Sowers [22] }\end{array}$ \\
\hline $\mathrm{C}_{\mathrm{c}}=0.008(\mathrm{LL}-12)$ & All Clays & $\begin{array}{l}\text { Sridharan and } \\
\text { Nagaraj [24] }\end{array}$ \\
\hline $\mathrm{C}_{\mathrm{c}}=0.014(\mathrm{PI}+3.6)$ & All Clays & $\begin{array}{l}\text { Sridharan and } \\
\text { Nagaraj [24] }\end{array}$ \\
\hline $\mathrm{C}_{\mathrm{c}}=0.007(\mathrm{SI}+18)$ & All Clays & $\begin{array}{l}\text { Sridharan and } \\
\text { Nagaraj [24] }\end{array}$ \\
\hline $\begin{array}{l}\mathrm{C}_{\mathrm{c}}=0.0075 \mathrm{LL} \text { For } \mathrm{A}<1 \\
\mathrm{C}_{\mathrm{c}}=0.012 \mathrm{LL} \text { For } \mathrm{A}>1\end{array}$ & $\begin{array}{l}\text { Remolded } \\
\text { Clays }\end{array}$ & $\begin{array}{l}\text { Tiwari and } \\
\text { Beena [26] }\end{array}$ \\
\hline $\mathrm{C}_{\mathrm{c}}=0.009 \mathrm{LL}$ & $\begin{array}{l}\text { Tokyo Bay } \\
\text { Clays }\end{array}$ & Tsuchida [27] \\
\hline$C_{c}=0.009(L L-8)$ & $\begin{array}{c}\text { Tokyo Bay } \\
\text { Clays }\end{array}$ & Tsuchida [27] \\
\hline $\mathrm{C}_{\mathrm{c}}=0.5 \mathrm{PI} \mathrm{Gs}$ & $\begin{array}{l}\text { Remolded } \\
\text { Clays }\end{array}$ & $\begin{array}{c}\text { Wroth and Wood } \\
\text { [29] }\end{array}$ \\
\hline $\mathrm{C}_{\mathrm{c}}=0.0037(\mathrm{MLL}+17.81)$ & $\begin{array}{c}\text { Compacted } \\
\text { Clays }\end{array}$ & $\begin{array}{l}\text { Ratnam and } \\
\text { Parsad [34] }\end{array}$ \\
\hline $\begin{array}{l}\text { Note: } \mathrm{C}_{\mathrm{c}} \text { is Compression } \\
\text { Liquid Limit, MLL is } \mathrm{m} \\
\text { Index, } \mathrm{SI} \text { is Shrinkage Ind } \\
\text { at Liquid limit, A is Activ }\end{array}$ & $\begin{array}{l}\text { dex, } \mathrm{C}_{\mathrm{c}}{ }^{\prime} \text { is Com } \\
\text { dified Liquid L } \\
\text {, e } \mathrm{e}_{0} \text { Initial Void } \\
\mathrm{y} \text { of soil }\end{array}$ & $\begin{array}{l}\text { ession ratio, LL is } \\
\text { it, PI is Plasticity } \\
\text { atio, } e_{L} \text { Void Ratio }\end{array}$ \\
\hline
\end{tabular}

A standard compaction test was done on artificially mixed soil samples. The OMC of these samples was ranging from $14.8 \%$ to $27 \%$, and maximum dry density was in the range of $14.2 \mathrm{kN} / \mathrm{m}^{3}$ to 17.27

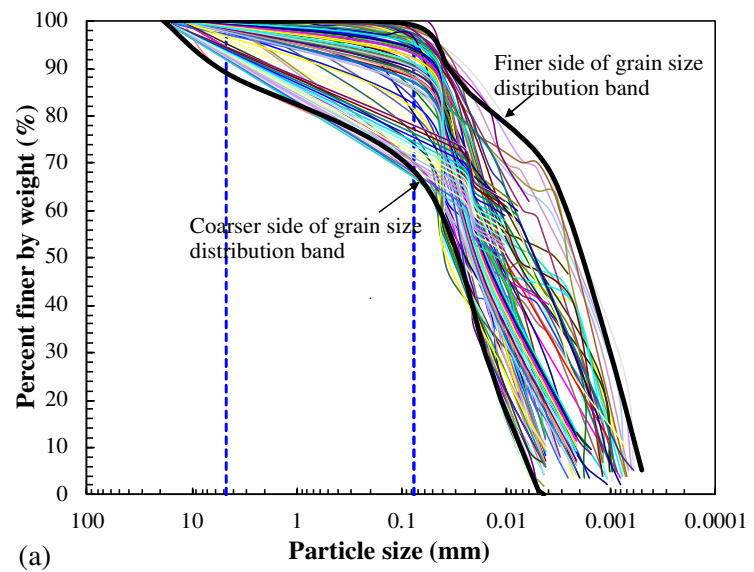

Fig. 2(a): Grain-Size Distribution Curves

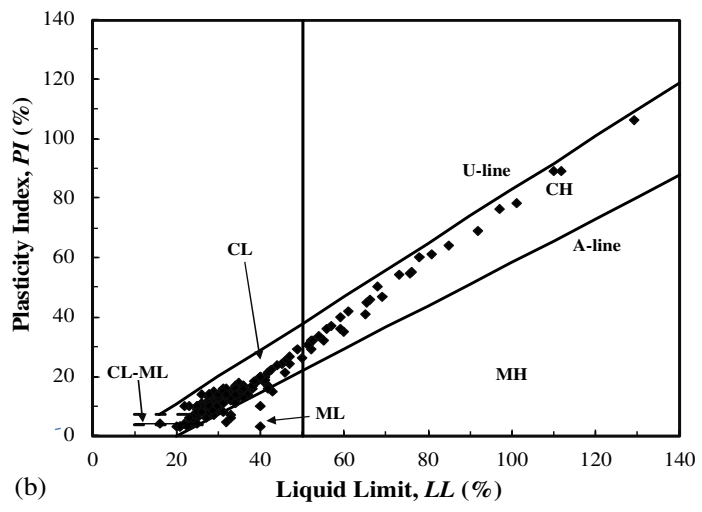

Fig. 2(b) Plasticity Chart

Fig. 2: Physical Characteristics of Soil Samples

$\mathrm{kN} / \mathrm{m}^{3}$. At the same time, with the addition of bentonite in the soil, maximum dry density was observed to decrease, and optimum moisture content was increased. The decrease in dry density of soil samples can be attributed to the formation of the diffused double layer around the soil particles, which tends to enhance the effective soil particle size, due to high of fragment of active clay minerals present in the bentonite; consequently, it increases the void ratio and decreases the dry density of the soil. The compression index, coefficient of volume compressibility and compression ratio were determined from consolidation tests. The compression index was determined through the slope of the virgin curve obtained from the e-log $(\mathrm{P})$ plot. Whereas, the $\mathrm{m}_{\mathrm{v}}$ value was determined for a pressure range of $100-200 \mathrm{kPa}$ as per specifications of British standards (BS 1377) [45, 46]. It was observed that for the subjected samples, $C_{c}$ was ranged from 
0.07 to 0.92 , the $\mathrm{m}_{\mathrm{v}}$ values were ranged from $0.1-0.80$ $1 / \mathrm{MN}$, and the $\mathrm{C}_{\mathrm{c}}{ }^{\prime}$ was in the range of 0.07-0.35.

\section{DEVELOPMENT OF CORRELATIONS}

Overall, the database of the present study was comprised of 190 soil samples regarded as data sets. Index properties and compressibility indices of 178 data sets were determined as per the exhaustive experimental investigation plan of the present study, as described in the previous section. Out of these data sets, a database containing 150 data sets was utilized to conduct a statistical analysis to establish some strong and straightforward relationships for estimating the compressibility parameters of the cohesive soils. Table 2 summarizes the database utilized for the development of correlations. To avoid complexity, which is indeed aimed in the present study, while using any correlation for a quick preliminary prediction, numerous linear regression correlations were established, and most suitable and pragmatic correlations were identified based on the parametric study. Parametric analysis of the regression correlations revealed that the LL and PI values yielded the most valid and reliable relationship with $\mathrm{C}_{\mathrm{c}}, \mathrm{C}_{\mathrm{c}}$, and $\mathrm{m}_{\mathrm{v}}$ values. Thus, different correlations were established to envisage $C_{c}, C_{c}{ }^{\prime}$, and $m_{v}$ values using LL and PI values as variables. Moreover, it is pertinent to note that correlations between compressibility characteristics and other index properties having less reliability are not discussed in this paper.

\subsection{Correlations Based on the Liquid limit}

Experimental test results revealed that the values of consolidation parameters of the cohesive soils increased significantly with an increase in the LL; such a trend is obviously in line with the past studies [4, 11]. In the present study, correlations were developed to envisage $C_{c}, C_{c}{ }^{\prime}$, and $m_{v}$ values based on the LL. Fig. 3(a-c) presents the relationship of the LL with $C_{c}, C_{c}{ }^{\prime}$, and $m_{v}$, respectively. It is pertinent to mention that the coefficient of determination $\left(\mathrm{R}^{2}\right)$ value is regarded as a significant statistical index to evaluate the correlation's health [47-54]. Such a coefficient was calculated for each correlation based on the standard deviation and the number of data sets utilized in developing relevant correlation. $\mathrm{R}^{2}$ values for the correlations for the $\mathrm{C}_{\mathrm{c}}, \mathrm{C}_{\mathrm{c}}{ }^{\prime}$, and $\mathrm{m}_{\mathrm{v}}$ values based on the LL were determined to be $0.95,0.91,0.80$ respectively, demonstrating the excellent strength of these correlations. Thus, the following correlations were developed with a good coefficient of determination.

$\mathrm{C}_{\mathrm{c}}=0.007(\mathrm{LL}-8.4)$

$\mathrm{C}_{\mathrm{c}}^{\prime}=0.003(\mathrm{LL}+2.23)$

$\mathrm{m}_{\mathrm{v}}=0.006(\mathrm{LL}+6.93)$

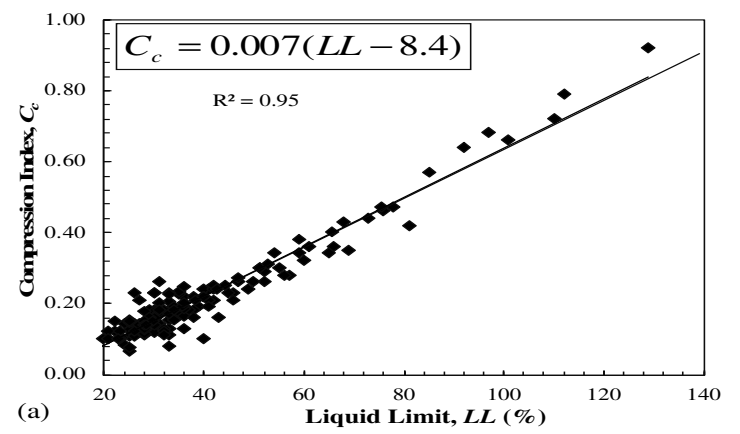

(a) Compression Index

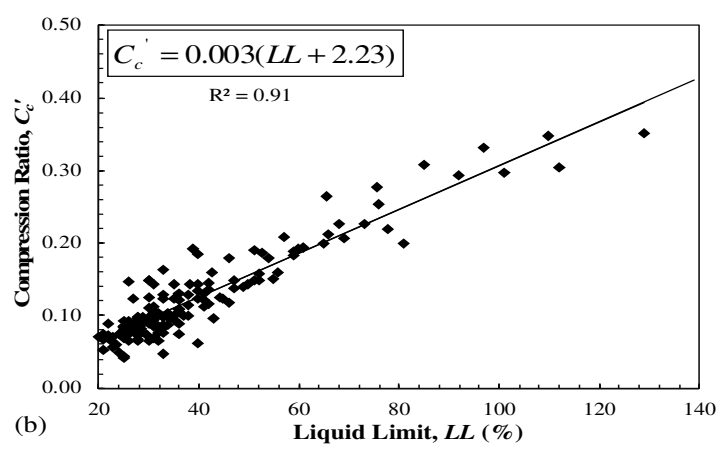

(b) Compression Ratio

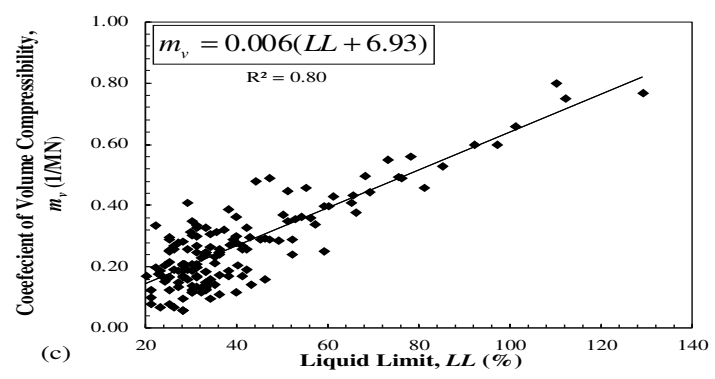

(c) Coefficient of Volume Compressibility

Fig. 3: Relationships of Liquid Limit

\subsection{Correlations Based on the Plasticity Index}

Similar to the liquid limit, it was observed that with the increase in PI of the cohesive soils, compressibility 


\begin{tabular}{|c|c|c|c|c|c|c|c|c|c|c|c|c|c|}
\hline $\begin{array}{l}\text { Type of } \\
\text { Samples }\end{array}$ & $\frac{\tilde{u}}{\vec{a}}$ & $\begin{array}{l}\text { Grain } \\
\text { ASTM }\end{array}$ & ze Distrit & $\begin{array}{l}\text { ation } \\
4221\end{array}$ & $\begin{array}{r}\text { Atte } \\
\mathrm{L} \\
\mathrm{AS} \\
4\end{array}$ & $\begin{array}{l}\text { erg's } \\
\text { it } \\
4 \mathrm{D} \\
8\end{array}$ & 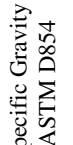 & In-Sitı & Characte & tics & & $\begin{array}{l}\text { solidati } \\
\text { rameter } \\
\text { ГМ D24 }\end{array}$ & \\
\hline USCS & $\dot{z}$ & $\begin{array}{l}\text { Sand } \\
(\%)\end{array}$ & $\begin{array}{l}\text { Silt } \\
(\%)\end{array}$ & $\begin{array}{l}\text { Clay } \\
(\%)\end{array}$ & $\begin{array}{l}\mathrm{LL} \\
(\%)\end{array}$ & $\begin{array}{c}\text { PI } \\
(\%)\end{array}$ & $\mathrm{G}_{\mathrm{s}}$ & $\begin{array}{c}\text { NMC } \\
(\%)\end{array}$ & $\begin{array}{c}\text { Dry } \\
\text { Density } \\
(\mathrm{kN} / \\
\left.\mathrm{m}^{3}\right) \\
\end{array}$ & $\begin{array}{c}\text { in- } \\
\text { void } \\
\text { ratio, } \\
e_{0} \\
\end{array}$ & $\mathrm{C}_{\mathrm{c}}$ & $\begin{array}{c}m_{v} \\
(1 / \mathrm{M} \\
\mathrm{N})\end{array}$ & $\mathrm{C}_{\mathrm{c}^{\prime}}$ \\
\hline $\mathrm{CH}$ & 30 & $\begin{array}{l}2.0- \\
7.0\end{array}$ & $26-55$ & $\begin{array}{l}41- \\
72 \\
\end{array}$ & $\begin{array}{l}52- \\
129 \\
\end{array}$ & $\begin{array}{l}32- \\
106\end{array}$ & $\begin{array}{l}2.68- \\
2.75 \\
\end{array}$ & $\begin{array}{c}15.79- \\
27 \\
\end{array}$ & $\begin{array}{c}13.97- \\
16.26 \\
\end{array}$ & $\begin{array}{c}0.63- \\
1.62 \\
\end{array}$ & $\begin{array}{c}0.26- \\
0.92 \\
\end{array}$ & $\begin{array}{c}0.29- \\
0.80 \\
\end{array}$ & $\begin{array}{r}0.14- \\
0.35 \\
\end{array}$ \\
\hline $\mathrm{CL}$ & 106 & $1.0-27$ & $52-87$ & $\begin{array}{c}9.0- \\
40 \\
\end{array}$ & $\begin{array}{c}30- \\
49 \\
\end{array}$ & $\begin{array}{c}11.0- \\
29\end{array}$ & $\begin{array}{l}2.65- \\
2.72 \\
\end{array}$ & $8.3-33$ & $\begin{array}{c}13.95- \\
17.3 \\
\end{array}$ & $\begin{array}{c}0.49- \\
1.04 \\
\end{array}$ & $\begin{array}{c}0.07- \\
0.25 \\
\end{array}$ & $\begin{array}{c}0.10- \\
0.41 \\
\end{array}$ & $\begin{array}{r}0.04- \\
0.18 \\
\end{array}$ \\
\hline CL-ML & 10 & $1.0-32$ & $63-93$ & $\begin{array}{l}5.0- \\
7.0 \\
\end{array}$ & $\begin{array}{l}22- \\
29 \\
\end{array}$ & $\begin{array}{c}4.0- \\
7.0 \\
\end{array}$ & $\begin{array}{c}2.68- \\
2.70 \\
\end{array}$ & $\begin{array}{l}8.7- \\
25.4 \\
\end{array}$ & $\begin{array}{c}13.76- \\
15.6 \\
\end{array}$ & $\begin{array}{c}0.68- \\
0.9 \\
\end{array}$ & $\begin{array}{c}0.14- \\
0.18 \\
\end{array}$ & $\begin{array}{c}0.15- \\
0.38 \\
\end{array}$ & $\begin{array}{c}0.07- \\
0.10 \\
\end{array}$ \\
\hline ML & 4 & $\begin{array}{l}1.0- \\
2.0\end{array}$ & $88-94$ & $\begin{array}{c}4.0- \\
11 \\
\end{array}$ & $\begin{array}{c}33- \\
40 \\
\end{array}$ & $\begin{array}{c}2.0- \\
10 \\
\end{array}$ & $\begin{array}{l}2.65- \\
2.70 \\
\end{array}$ & $\begin{array}{c}2.31- \\
8.6 \\
\end{array}$ & $\begin{array}{l}14.4- \\
15.34 \\
\end{array}$ & $\begin{array}{c}0.79- \\
0.85 \\
\end{array}$ & $\begin{array}{c}0.23- \\
0.24 \\
\end{array}$ & $\begin{array}{c}0.18- \\
0.25 \\
\end{array}$ & $\begin{array}{l}0.12- \\
0.13 \\
\end{array}$ \\
\hline Overall & 150 & $1.0-32$ & $26-94$ & $\begin{array}{c}4.0- \\
72 \\
\end{array}$ & $\begin{array}{l}22- \\
129\end{array}$ & $\begin{array}{l}2.0- \\
106\end{array}$ & $\begin{array}{l}2.65- \\
2.75\end{array}$ & $\begin{array}{c}2.31- \\
27\end{array}$ & $\begin{array}{c}13.76- \\
17.3 \\
\end{array}$ & $\begin{array}{c}0.49- \\
1.62\end{array}$ & $\begin{array}{c}0.07- \\
0.92\end{array}$ & $\begin{array}{c}0.10- \\
0.80\end{array}$ & $\begin{array}{c}0.07- \\
0.35 \\
\end{array}$ \\
\hline
\end{tabular}

tended to increase evidently. In the present study, correlations were established for the $\mathrm{C}_{\mathrm{c}}, \mathrm{C}_{\mathrm{c}}{ }^{\prime}$, and $\mathrm{m}_{\mathrm{v}}$ values based on the PI as well. Fig. 4(a-c) presents the relationship of the PI with $\mathrm{C}_{\mathrm{c}}, \mathrm{C}_{\mathrm{c}}{ }^{\prime}$ and $\mathrm{m}_{\mathrm{v}}$, respectively. The value $\mathrm{R}^{2}$ for the correlations for the $\mathrm{C}_{\mathrm{c}}, \mathrm{C}_{\mathrm{c}}{ }^{\prime}$, and $m_{v}$, based on PI, was calculated to be almost $0.94,0.81$, 0.72 , respectively, rendering the excellent strength of these correlations. Thus, the following correlations were developed with a good coefficient of determination.

$\mathrm{C}_{\mathrm{c}}=0.0072(\mathrm{PI}+10.9)$

$\mathrm{C}_{\mathrm{c}}^{\prime}=0.003(\mathrm{PI}+21.65)$

$\mathrm{m}_{\mathrm{v}}=0.0058(\mathrm{PI}+27.2)$

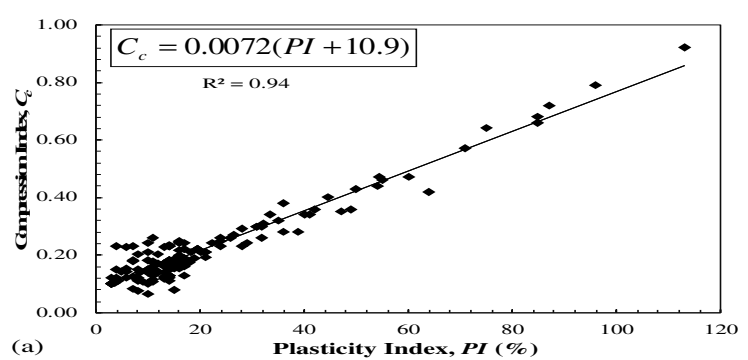

(a) Compression Index

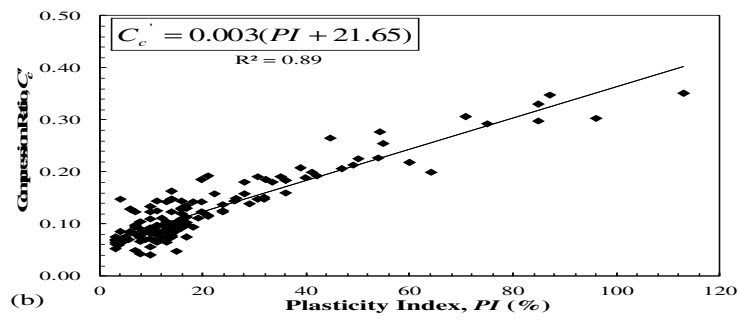

(b) Compression Ratio

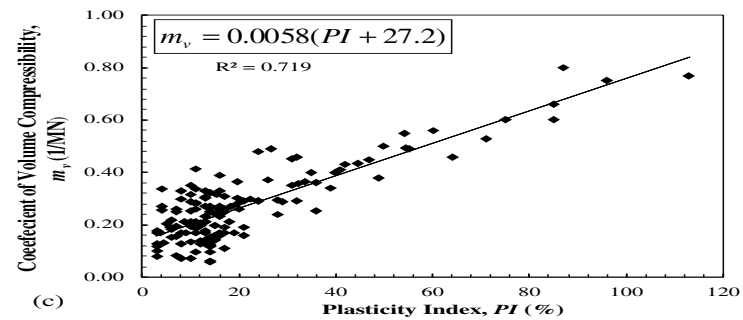

(c) Coefficient of Volume Compressibility

Fig. 4: Relationships of Plasticity Index

\section{VERIFICATION OF DEVELOPED CORRELATIONS}

Finally, the verification of the performance of the developed correlations was carried out to determine their reliability. For this purpose, 28 more soil specimens which were not included in the establishment of correlations, and were independently tested. Data on consolidation parameters and index properties of 12 more samples were also aquired from the past literature. A set of 40 samples was utilized for verification purposes; a summary of consolidation parameters and index properties of these samples are presented in Table 3. Experimental values of consolidation parameters $\left(C_{c}, C_{c}\right.$ ' and $\left.m_{v}\right)$ were plotted against predicted values of these consolidation parameters by the developed correlations. The validity of correlations for $C_{c}$ was checked based on a database of 40 samples, whereas the validity of correlations for $C_{c}{ }^{\prime}$ and $\mathrm{m}_{\mathrm{v}}$ was checked based on a database of 28 
samples due to the unavailability of data of these parameters in the literature.

Percentage deviation from $45^{0}$-line (equality line) was calculated by the given formula;

Percentage Deviation $=\frac{100 \%}{n} \sum_{t=1}^{n}\left(\frac{A_{t}-P_{t}}{A_{t}}\right)$

where, $A_{t}, P_{t}$ and $n$ are the actual value, envisaged value, and value entry, respectively.

\subsection{Correlations Based on Liquid Limit}

Experimental values of consolidation parameters $\left(\mathrm{C}_{\mathrm{c}}\right.$, $\mathrm{C}_{\mathrm{c}}{ }^{\prime}$ and $\mathrm{m}_{\mathrm{v}}$ ) were plotted against the envisaged values of these consolidation parameters using the equations established on the basis of the LL. It was observed that the percentage deviation among predicted values from equations 3, 4, and 5 and experimental values, from the equality line, was in the range of $\pm 7, \pm 8.3$ and \pm 8.5 (Fig. 5). Values of consolidation parameters were also predicted from correlations developed by several researchers and compared with the relevant correlations established in the present study [1, 2, 4, 16]. It was observed that the correlations established in the present study showed less percentage error in the prediction as compared to the previously developed correlations (Fig. 5).

\subsection{Correlations Based on the Plasticity Index}

Experimental values of consolidation parameters $\left(\mathrm{C}_{c}\right.$, $\mathrm{C}_{\mathrm{c}}$ ' and $\mathrm{m}_{\mathrm{v}}$ ) were plotted against the envisaged values of these consolidation parameters using the equations based on the PI. It was observed that the values

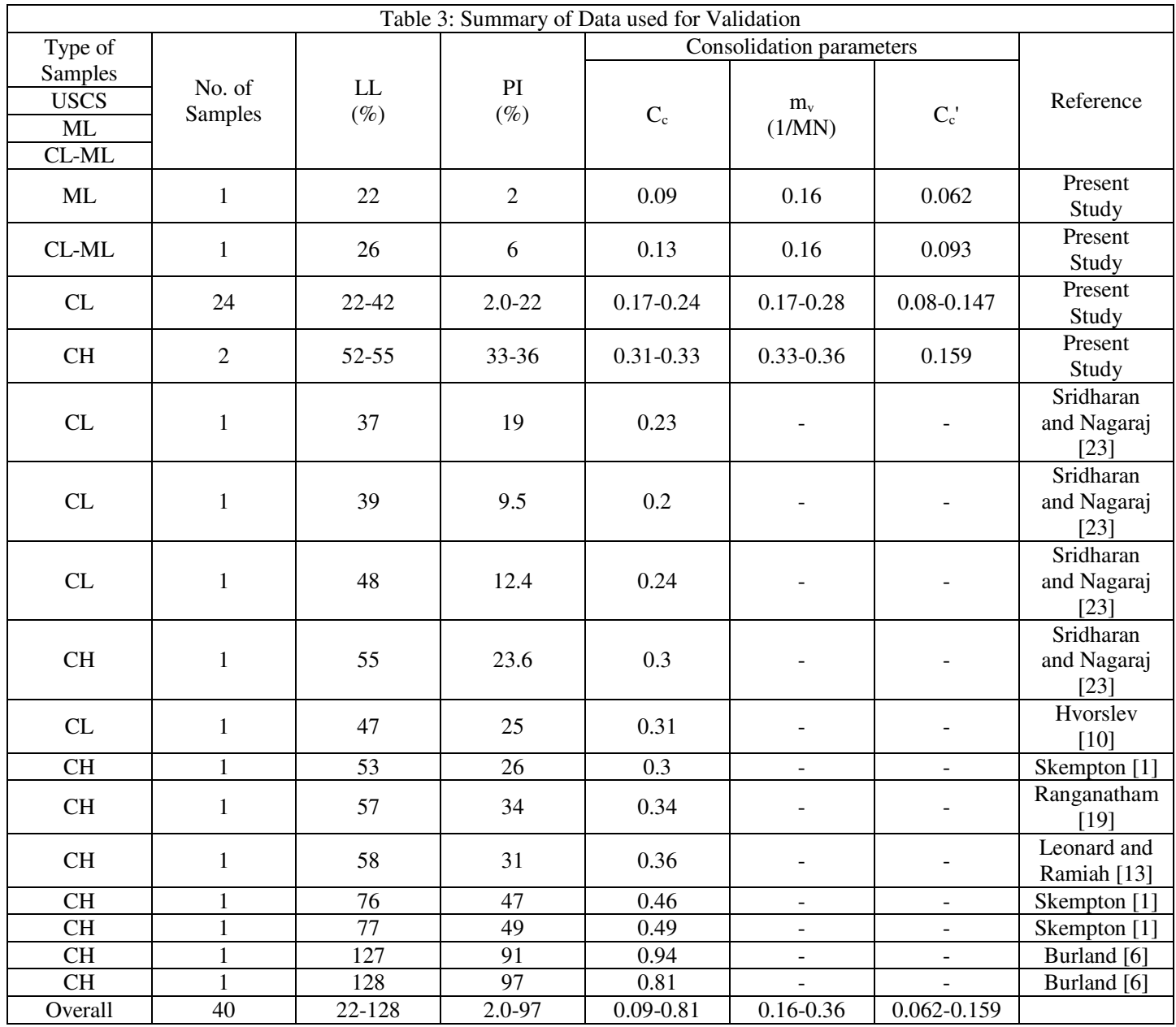




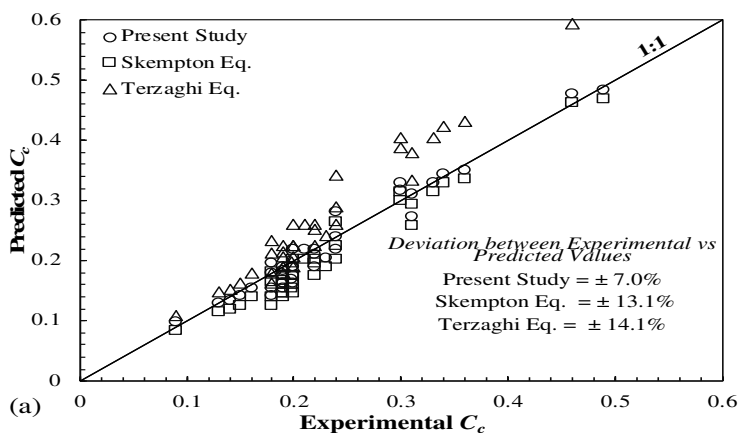

(a) Compression Index

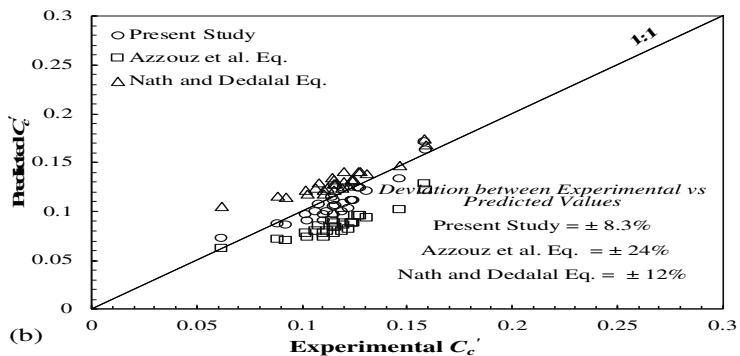

(b) Compression Ratio

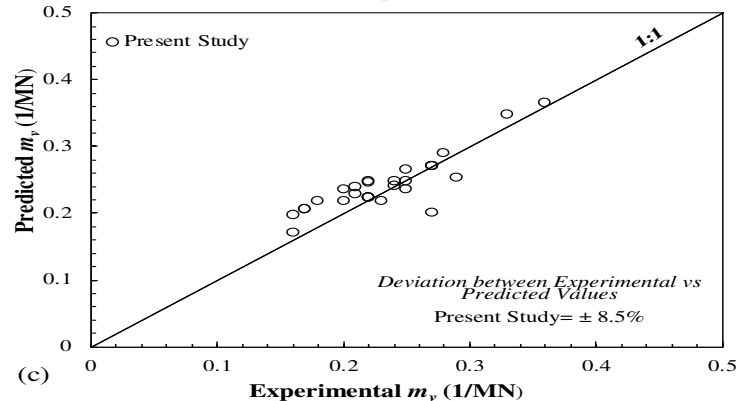

(c) Coefficient of Volume Compressiblity

Fig. 5: Comparison between Experimental Vs Predicted Values of Compression Index Based on Liquid Limit

predicted from equations 6,7 , and 8 were in the range of $\pm 6.7, \pm 6.1$ and \pm 7.3 (Fig. 6). Values of consolidation parameters were also predicted from correlations developed by Nath and Dedalal [16] and Amardeep and Shahid [21] and compared with relevant correlations developed in the present study (Fig. 6). Such a comparison presented that correlations developed in the present study showed less percentage deviation among predicted and experimental values. Moreover, it was also observed that correlations developed based on the PI are slightly more reliable based on the percentage deviation in the prediction of consolidation parameters as compared to correlations developed based on the liquid limit.

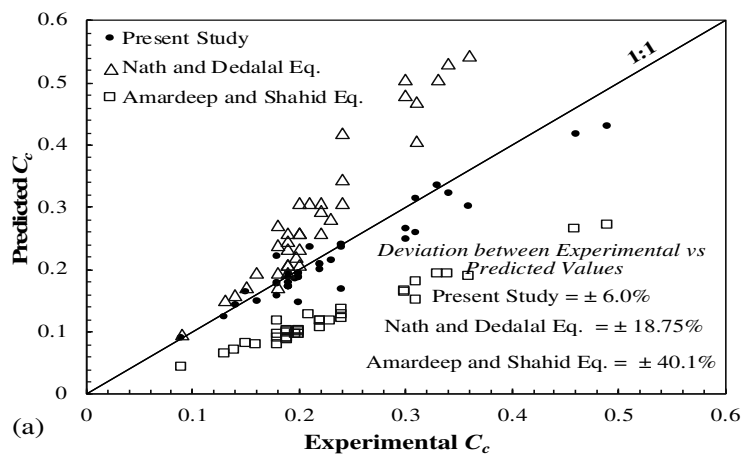

(a) Compression Index

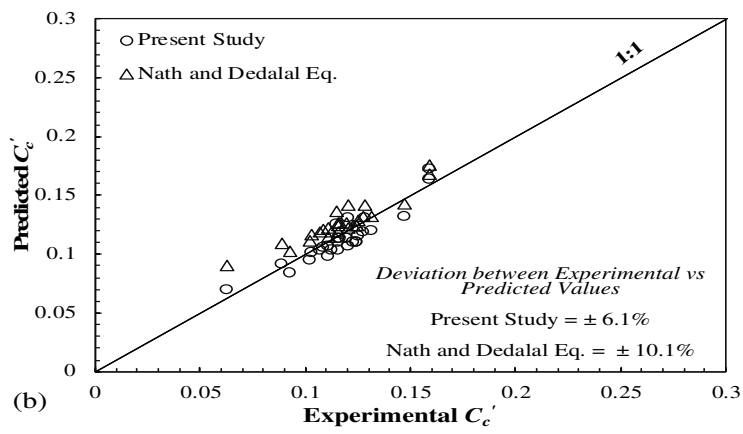

(b) Compression Ratio

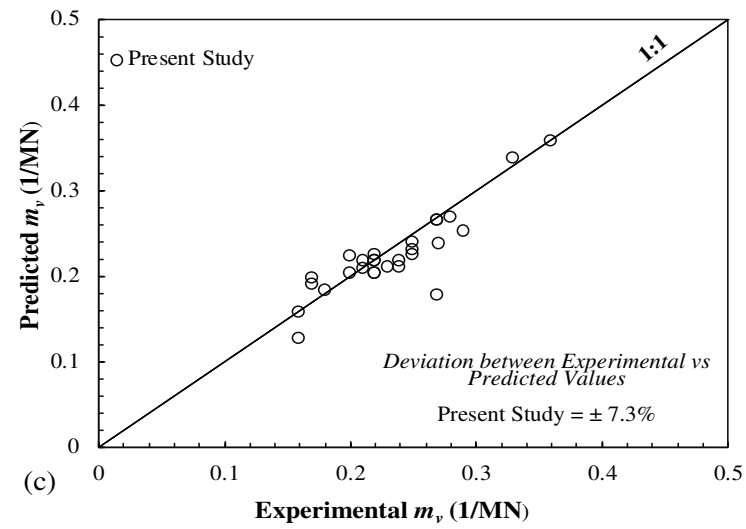

(c) Coefficient of Volume Compressibiliy

Fig. 6: Comparison between Experimental Vs Predicted Values of Compression Index based on Plasticity Index

\section{CONCLUSIONS}

(i) A large experimental database of the consolidation parameters is established by testing low to high plasticity range of the soils form Pakistan. The LL and PI of these soil samples are in the range of $22-129 \%$ and 4-106, respectively, and the soil samples are identified as ML, CL$\mathrm{ML}, \mathrm{CL}$ and $\mathrm{CH}$ as per the USCS classification system. 
(ii) Various generalized and straightforward correlations are established by conducting the statistical analysis on the established database for low to the high plasticity range of cohesive soil. Six correlations are finalized based on the parametric study to envisage the $\mathrm{C}_{\mathrm{c}}, \mathrm{C}_{\mathrm{c}}$, and $\mathrm{m}_{\mathrm{v}}$ values by using LL and PI as the variables, which are presented in Eqs. 3-8.

(iii) The performance of finalized correlations is also validated based on separate data set comprise of soil samples from various parts of Pakistan and literature. Such validation shows that the current correlations demonstrate excellent reliability on the data used for the validation, in envisaging the consolidation parameters as compared to some other available correlations in the literature. Percentage deviations from the equality line of the prediction for the current correlations are observed to be in the range of $\pm 6.1 \%$ to $\pm 8.5 \%$.

Moreover, it is pertinent to mention here that the correlations developed in this study could be of good use for the preliminary assessment of the consolidation parameters; however, such correlations cannot be the replacement of the actual tests; therefore, the authors declare the aforementioned statement as a limitation of the current study.

\section{ACKNOWLEDGEMENT}

Authors acknowledge the Department of Civil Engineering, University of Engineering \& Technology Lahore, Pakistan, for providing lab facility and technical support during the experimental phase of the present study.

\section{REFERENCES}

1. Skempton, A. W., "Notes on the Compressibility of Clays", Journal of the Geological Society, Vol. 102, No.1-4, pp. 205-209, 1946.

2. Terzaghi, K., "Soil Mechanics In Engineering Practice", John Wiley \& Sons, 1996.

3. Al-Khafaji, A., and Andersland, O., "Equations for Compression Index Approximation", Journal of Geotechnical Engineering, Vol. 118, No. 1, pp. 148-153, 1992.
4. Azzouz, A. S., Krizek, R. J., and Corotis, R. B., "Regression Analysis of Soil Compressibility," Soils and Foundations, Vol. 16, No. 1, pp. 19-29, 1976.

5. Bowles, J. E., "Physical And Geotechnical Properties Of Soils", 1989.

6. Burland, J. "On The Compressibility and Shear Strength of Natural Clays", Geotechnique, Vol. 40, No. 1, pp. 329-378, 1990.

7. Carrier N. III, "Consolidation parameters derived from index tests", Geotechnique, Vol. 35, No. 1, 1985.

8. Crumley, A. R., Fernández A. L., and Regalado, C. A., "Compressibility Relationships for Soils In Puerto Rico", Proceedings of 12th Panamerican Conference, Soil and Rock America, America, 2003.

9. Hough, B. K., "Basic Soil Engineering", The Ronald Press Company, New York., 1957.

10. Osterberg, J. O, "Personal Communication", 1972.

11. Koppula, S., "Statistical Estimation of Compression Index", ASTM Geotechnical Testing Journal, Vol. 4, No.1, 1981.

12. Kulhawy, F. H., and Mayne, P. W., "Manual On Estimating Soil Properties for Foundation Design", Geotechnical Engineering Group, Electric Power Research Institute., Palo Alto, CA (USA); Cornell Univ., Ithaca, New York, 1990.

13. Leonards, G., and Ramiah, B., "Time Effects in The Consolidation of Clays", Symposium of time rates of loading in soil testing, ASTM, Special Technical Publication, Vol. 1, No.1, pp. 116-130, 1960.

14. Cozzolino, V. M., "Statistical Forecasting of Compression Index", Proceedings of 5th International Conference on Soil Mechanics and Foundation Engineering, Vol. 1, No. 1, pp. 51-53, Paris, 1961.

15. Nagaraj, T., and Murthy, B. S., "A Critical Reappraisal of Compression Index Equations", Géotechnique, Vol. 36, No. 1, pp. 27-32, 1986.

16. Nath, A., and DeDalal, S., "The Role of Plasticity Index In Predicting Compression Behaviour Of Clays", Electronic Journal of Geotechnical Engineering, Vol. 9, No.1, pp. 1-7, 2004.

17. Nishida, Y., "A Brief Note on Compression Index of Soil", Journal of Soil Mechanics and 
Foundation Divison, Vol. 82, No. 3, pp. 1-14, 1956.

18. Park, J. and Koumoto, T., "New Compression Index Equation", Journal of Geotechnical and Geoenvironmental Engineering, Vol. 130, No. 1, pp. 223-226, 2004.

19. Ranganatham, B., "Soil Structure and Consolidation Characteristics of Black Cotton Clay", Geotechnique, Vol. 11, No. 1, pp. 333-338, 1961.

20. Rendon-Herrero, O., "Universal Compression Index Equation", Journal of the Geotechnical Engineering Division, Vol. 106, No. 1, pp. 11791200, 1980.

21. Amardeep, S. and Shahid, N., "Soil Compression Index Prediction Model for Fine Grained Soils", International Journal of Innovation Engineering and Technology, Vol. 1, No. 1, pp. 34-37, 2012.

22. Sowers, G. B., and Sowers, G. F., "Introductory Soil Mechanics and Foundations", Soil Science, Vol. 72, No. 1, pp. 405, 1951.

23. Sridharan, A., and Nagaraj, H., "Coefficient of Consolidation And Its Correlation With Index Properties Of Remolded Soils", Geotechnical Testing Journal, Vol. 27, No. 1, pp. 469-474, 2004.

24. Sridharan A., and Nagaraj, H., "Compressibility Behaviour of Remoulded, Fine-Grained Soils and Correlation with Index Properties", Canadian Geotechnical Journal, Vol. 37, No. 1, pp. 712722, 2000.

25. Coelho, P. A. L. F., and Lemos, L. J. L., "Compressibility Characteristics of a Portuguese Soft Deposit", Soft Soil Engineering, Vol. 1, No. 1, pp. 663-668. Routledge, 2017.

26. Tiwari, B., and Ajmera, B., "New Correlation Equations For Compression Index of Remolded Clays", Journal of Geotechnical and Geoenvironmental Engineering, Vol. 138, No. 1, pp. 757-762, 2011.

27. Tsuchida, T., "A New Concep of e-log p Relationship For Clays", Proceedings of 9th Asian Regional Conference onSoil Mechanics and Foundation Engineering, Bangkok, Vol. 1, No. 1, pp. 87-90, Thailand, 1991,

28. Widodo, S., and Ibrahim, A., "Estimation of Primary Compression Index (Cc) Using Physical Properties of Pontianak Soft Clay", International
Journal of Engineering Research and Applications, Vol. 2, No. 1, pp. 2232-2236, 2012.

29. Wroth, C., and Wood, D., "The Correlation of Index Properties with Some Basic Engineering Properties of Soils", Canadian Geotechnical Journal, Vol. 15, No. 1, pp. 137-145, 1978.

30. Yong, R. N., and Warkentin, B. P., "Introduction to Soil Behavior", Vol. 1, No. 451, 1966.

31. Verbrugge, J. C., and Schroeder, C., "Geotechnical Correlations For Soils and Rocks", John Wiley \& Sons, 2018.

32. Dagdeviren, U. Demir, A. S. and Kurnaz, T. F., "Evaluation of the Compressibility Parameters of Soils Using Soft Computing Methods", Soil Mechanics and Foundation Engineering, Vol. 55, No. 3, pp. 173-180, 2018.

33. Yoon, G. L. Kim, B. T. and Jeon, S. S., "Empirical Correlations of Compression Index For Marine Clay From Regression Analysis", Canadian Geotechnical Journal, Vol. 41, No. 1, pp. 12131221, 2004.

34. Ratnam, U. V., and Prasad, K. N., "Prediction of Compaction and Compressibility Characteristics of Compacted Soils", International Journal of Applied Engineering Research, Vol. 14, No. 3, pp. 621-632, 2019.

35. Sharma, S., Mishra, A. K., and Kumar, B., "Prediction of Coefficient of Consolidation Using Multi-Gene Genetic Programming", INAE Letters, Vol. 1, No. 1, pp. 1-7, 2019.

36. Rahman, Z. U., and Khan, A. A., "Selection of Best Fit Correlation for Compression Index of Soil from District Bannu", Mehran University Research Journal of Engineering and Technology, Vol. 38, No. 1, pp. 221, 2019.

37. Akbarimehr, D., and Aflaki, E., "Using Empirical Correlations to Evaluate the Compression Index of Tehran Clay", AUT Journal of Civil Engineering, Vol. 3, No. 1, pp. 129-136, 2019.

38. ASTM, D422. "Standard test method for particlesize analysis of soils", Annual Book of ASTM Standards, 2007.

39. ASTM, D4221-18., "Standard Test Method For Dispersive Characteristics Of Clay Soil By Double Hydrometer", Annual Book of ASTM Standards, 2007.

40. ASTM, D4318., "Standard Test Methods For Liquid Limit, Plastic Limit, And Plasticity Index 
Of Soil', Annual Book of ASTM Standards Volume 4, No. 8, 2000.

41. ASTM, D854-00., "Standard Test Method For Specific Gravity of Soil Solids By Water Pycnometer", Annual book of ASTM Standards, Volume 4, No. 8, 2002.

42. ASTM, D. 698., "Test Methods For Laboratory Compaction Characteristics of Soil Using Standard Effort (12,400 ft-lbf/ft $(600 \mathrm{kN}-\mathrm{m} / \mathrm{m})) "$, Annual Book of ASTM Standards, Volume 4, No. 8, 2000.

43. ASTM D2435-96., "Standard Test for One Dimensional Consolidation Properties of Soil", Annual book of ASTM Standards, 1999.

44. ASTM D2487., "Standard Practice For Classification Of Soils for Engineering Purposes (Unified Soil Classification System)", Annual Book of ASTM Standards, Vol. 4, No. 8, 2006.

45. STANDARD B., "Eurocode 7: Geotechnical Design", 2004.

46. Craig, R. F., "Craig's Soil Mechanics", CRC Press, 2004.

47. Rehman, Z. U. Khalid, U. Farooq, K. and Mujtaba, H., "Prediction of CBR Value from Index Properties of different Soils", Technical Journal, Vol. 22, No. 2, pp. 17-26, 2017.

48. Farooq, K. Khalid, U. Mujtaba, H., "Prediction of Compaction Characteristics of Fine-Grained Soils Using Consistency Limits", Arabian Journal of Science and Engineering, Vol. 41, No. 4, pp. 1319-1328, 2016.

49. Khalid, U. and Rehman, Z. U., "Evaluation Of Compaction Parameters Of Fine-Grained Soils Using Standard And Modified Effort", International Journal of Geo-Engineering, Vol. 9, No. 1, pp. 1-15, 2018.

50. Rehman, Z. U., Khalid, U., Farooq, K. and Hassan, M., "On Yield Stress of Compacted Soils", International Journal of Geo-Engineering, Vol. 9, No. 1, pp. 1-21, 2018.

51. Khalid, U., Rehman, Z. U., Liao, C. Farooq, K. and Hassan, M., "Compressibility of Compacted Clays Mixed With a Wide Range of Bentonite for Engineered Barriers", Arabian Journal of Science and Engineering, Vol. 44, No. 5, pp. 5027-5042, 2019.

52. Khalid, U., Liao, C. C., Ye, G. L., and Yadav, S. K. "Sustainable Improvement of Soft Marine Clay
Using Low Cement Content: a Multi-Scale Experimental Investigation", Construction and Building Materials, Vol. 191, No. 1, pp. 469-480.

53. Iqbal, F., Kumar, A., and Murtaza, A., "CoRelationship between California Bearing Ratio and Index Properties of Jamshoro Soil", Mehran University Research Journal of Engineering and Technology, Vol. 37, No.1, pp. 177-190, 2018.

54. Rehman, Z.U., Khalid, U., and Mahmood, K., "Experimental Evaluation of Mohr Columb Strength Parameter with Grain Size of Granular Soils", Technical Journal, Vol. 24, No.3, pp. 8-14, 2019. 